\title{
Free Public Service in The Perspective of Government's Management
}

\author{
Syarief Makhya ${ }^{1}$ \\ ${ }^{1}$ Faculty of Social and Political Science, Lampung University, \\ (symakhya@yahoo.com)
}

\begin{abstract}
After the new order government, public services in several regions such as the health services, education services and civil services are free of charge particularly for the poor people. Furthermore, the poor are free of charge in obtaining public services. In this perspective, obviously, people have a basic right as the citizen in order to achieve government services. However, by releasing the free of charge policy for the people, government has applied the logic of in-efficiency in delivering services for the people. As the result, the government has to provide extra budget for subsidising several public services. Moreover, the logic of in-efficiency is an alternative value and it is also part of government's duties in realising interests of the poor people. Furthermore, the logic of In-efficiency particularly the case of free public service policies are the consequence of implementation of the political contract between public officials and communities.

However, the role of government in providing free public services are not in an ideal circumstances. It has to be understood that the free public services are not only services function but also political imagery and it is also part of political contract to society. Thus, the definition of public service is likely to be defined only in the perspective of political elites/authorities.

Comprehensively, pro poor policy principles can be realised immediately. By releasing free public services for the poor, It will dismiss the assumption that the government has limited financial resources. Furthermore, it causes the government ought to work on both efficiency and maximum the economic advantages. Unfortunately, it is not a sufficient reason for the government to be stand behind the poor. Finally, the values have mentioned in the government mission will create a pro poor government management which based on the principle of equality and justice. Obviously, the sustainability of policies will depend on who will be elected as the public officials.
\end{abstract}

Key Words: Free Public Service, In - Efficiency, The Poor People

\section{Introduction}

In the New Order, the functions of government in the provision of public service -oriented dominantinterests of consumers. The consumers were the people who have gained access to financial services.In that era, there was no such free service, but there was payment relief for patients who were not able to be categorized (Makhya, 1997). Basically, Health services at health clinics provided by the government which did not become free, the procedure of clinics must be paid even though the price was very cheap and relatively affordable for the poor. Such in the case of public services, in the field of education, and also the civil service (such as: make birth certificateand identity cards) in the New Order were not free.
In the early post of New Order, as along the direct local elections, public service were applied and used as an important political issue to conduct political imagery and mobilize political support from the community. The implication of the program was the issue about a free public service becomes a magnet for public attention. Public services were considered as bad, expensive, complicated, and illegal fees, served as issues to be reformed by fixing the system of care and provide free services for people who were poor or can not afford.

Therefore, in several areas such as Bandar Lampung ${ }^{1}$, a free public service became a campaign theme forone of the candidates mayor Herman HN. When

\footnotetext{
$\left.{ }^{1}\right)$ For the purposes ofthis paperwillbe givenfreepublic servicein Bandar Lampungunder theleadership ofMayor of Bandar Lampung 2010-2015 period
} 
he was elected to behead a free public service areas, it was becoming a political contract into planning documents in the Medium Term Development Plan (RPJM)that must be implemented.

\section{Problems}

How to explain the phenomenon of a free public service administration in management studies? Is the phenomenon a part of a reform of the public service system or simply as a consequence of the political process?

\section{Discussion}

\subsection{Value of Government and Public Service Management}

In the perspective of government management, the role of government in the provision of public service functions has orientation which is more emphasis on resource utilization for a specific target group. The orientation is emphasized for people who are categorized as they have access to government services is a manifestation of the logic of the application of section efficiency or economic value. The implications of the economic value of efficiency and the function of government in the provision of basic services (education and health) or civil services (birth certificate , family card and ID card ) are not within the context of reaching all levels of society, because the government has limitation to subsidies, so that affects the cost of servicing portion should be charged to the public .

In this perspective, the people who are not able to be categorized as poor essentially not given access to the public services, because there are no regulatory policies that specifically provide free public services to the poor. Such case of government subsidy is not sufficient for the poor in obtaining public services. Even if there are regulations or policies that provide public services for health and education are liberating for the poor, the government's role is very limited and the policies tend to besymbolic. This phenomenon suggests that the role of government is not articulating the interests of the poor to get public services, because it is a trade off efficiency with other values, is the value equation in obtaining services for all segments of society.

Post- New Order government, there were political changes of the system of authoritarianism to democratic political systems. The Changes in the political system affected the system of local government management. One impact of the political changes that were relevant to the discussion of this paper are ( 1 ) the reform of the public service system;(2) the demands of government functions ; and (3) the change of government managers.

\section{A. Public Service Reform}

After the new order government, the public service system was reformed to follow the demands of society and the dynamics that occur in the local government. Therefore, local public services did not have the same quality standards, each region breakthrough innovation and public service isdifferent. Indonesia Rapid Decentralization Appraisal (IRDA) results (Satriyo et al, 2003) indicated that there were a number of areas that had best practices in the field of public policy, community development, health care, and controlling). In addition, the results of research conducted Prasojo et al (2004) found the practice in the development of innovation in the public service in some areas, such as Deli Serdang in economic empowerment coastal communities, with programs Gianjar, Gianjar District Welfare; East Sumbawa with village government personnel training programs, and Jembrana with innovative programs are some local government that have best practice regional 
autonomy. The results of these studies indicate that the result of bureaucracyreform affects delivery public services in the Region.

Another aspect that stands out wasas along a process of direct local elections, the issue of public service used to attract any strategic issues and mobilize public support for the head of local government candidate. Public service issues were passed in the New Order, such as the in- efficiency of services (pathology - bureaucracy), thecomplicated procedures,take a long time, the cost of expensive services, etc. The issues were used as a strategic issue to be created as the campaign materials. Eventually, there was discourse or political campaign promises raised, such as free education and health care, onestop service, and excellent service.

By regarding phenomenon, the issue of public services from the perspective of politics serves to make competition for political race for public occupation in government. In the perspective of government management, the issue of free public service hasput the role of government to intervene the regulation of both aspects of the budget subsidy or intervention to be used as the basis for answering the issue of limited access for the poor to get public services provided by the government.

\section{Demands of Government Functions}

In the era of democratic governance, the interaction between the government and the public increasingly dynamic can be seen as the emergence of a high level of government responsiveness to the demands of the aspirations and rights of citizens. Free public service is a consequence of the dynamic growth of the government in responding to the demands and rights of the public in obtaining government services.

According to Heywood (2002), the government's role by freeing payment for public service is part of the function of government to perform the functions of stability and order that resolve the conflict.The result of the role are consequences and the policy produces consensus, a balance between response and effectiveness; the ability to absorb and accommodate the expectations of the people in the formulation by maintaining the effectiveness of governmentas well as encouraging in the sense of social justice and human rights. Second, the government in providing material welfare, characterized as the following: addressing poverty, distribution of goods, and that it constitutes welfare society, as well as keeping social interest, warranted access to the necessities of life. Third, the government for citizenship, namely: a guarantee relating to gain social status in the minimum standard.

\section{Change Governance Manager}

Post-New Order administration management process of regional government, the region government also experienced fundamental change. As a result ofdirectlocal elections, powers were centralized at the head of local government. The position and role of regional head werev ery dominant in the policymaking process. The role is not only limited to how to control the state bureaucracy, but also as long occopied the position in office, the head of the area had a lot of interests that namely (a) the realization of public interest that was individualistic2). In this role, the programs should be his political campaign and priority programs to be implemented; (b) establishes and maintain political network. Head of local government must build a political network with members of the legislative support, also supported base that government stability was maintained, and legitimacy notdisturbed; (c) consolidatesupport

2) Individualisticpublic interestwhich describesthe public interestasa reflectionordominatedbythe interestsof powerful individuals(Harmon, 1969) 
internal-bureaucracy. The realization of this role was done by personnel transfers or rolling echelon; and (d) bound the movement of his political rivals. The role of regional head in restricting the role of vice head of local government, because the role assumed as political rival, both for the benefit seize the economic benefits of the project budget, or for the benefit of political competition in the selection of the second period.

By regarding from the perspective of the interests of the role of the head of local government suggests the strengthening of the role of head of local government as a manager of a politician is strong political interests inherent in the head of local government in managing governance.

\subsection{Logic Free of Charge in Obtaining Public} Services

Free public service from the perspective of government management embodies the mission of the regional head for political gain. Thus, free services of political interests of regional heads areso powerful in determining the impact of service policy. By the implication, the nature or character of government management in the delivery of public services is no longer at the level to pursue interests or the interests of economic efficiency. However, as the poor placed as citizens (citizenship) must obtain the fundamental rights in the field of basic services (health and education) and civil service (ID card, family certificate and birth certificate), it is precisely the value of in- efficiency should be an option. The implication, then the government should allocate funds to subsidize the free service.

The budget for the free public services sourced from APBD (Local Budget of Revenue and Expenditure). The case of free services in Bandar Lampung, the government spent 32.5 billion for education and for health services reach approximately 30 billion sourced from local budget. This fact shows that free public service requires no small budget. Therefore, the government is also required to be skilled in finding and increasing revenue. In Bandar Lampung, educational services, health and civil services are supported by the Mayor 's ability to increase revenue . PAD (Local Government Own Income) in Bandar Lampung in 2010 only reached 84 billion, in the year 2013 rose to 418 billion (Teras, 2014 ).

Accordingly, there is a way to eliminate most rationally public services option by increasing revenue sources primarilyfrom taxes and levies sector to increase revenue. However, if the local government would do a free service, it must be supported by adequate funding sources.

In that perspective, the availability of fund is an important factor in the management of a modern government. The mission can be applied by the principles of justice that would be implemented by the government to subsidize the poor for obtaining public services.

Free public service policy is a manifestation of an attempt to apply the principle of access for all people equity without exception for public services. This policy supported by increasing tax revenues and user fees, the group targets are entrepreneurs and community income / high income.

\section{Conclusions}

Government policies in favor of the poor principally can be done in a way to exempt public service. The policies provide free public services to dismiss the assumption that the government has limited financial resources led the government. The government should work on both efficiency or maximize the economic benefits, the government had not enough reason to be in pro- side for poor communities. 
As a result, the value of which is reflected in the mission of government will form a government in favor of management to serve the society based on the principles of equality and fairness. However, government efforts to realize a free public service are still very dependent on the public interest which is individualistic. If a change of head district with no bias against the poor, it is possibly the poor will still not have access to public services.

\section{References}

(1) Heywood, Andrew.(2002). Politics . Palgrave Foundations, J.W. Great Birtain:ArrowsmithLtd. Bristol,.

(2) Harmon , M. M. (1969). Administrative Policy Formulation and Public Interes.New York: Harper \& Row.

(3) Makhya. Syarief. (1997). Community Access In Getting Health Services. Thesis.University of Brawijaya. Malang

(4) Prasojo, Eko; Kurniawan, True; Hasan, Anwar. (2004). Bureaucratic Reform in Practice,: Center for the Study of Regional Developmentand Municipal Administration,.In Satriyo, Hana A.;Abidin,Adi; Kusdaryanto, Hari;Bulosan, Luce Agnes.Indonesia Rapid Decentralization Appraisal ( IRDA). Report to Three, July 2003. The Asia Foundationand Faculty of Social and Political Sciences, University of Indonesia (5) Teras. Magazine. February 2014. Serang, Banten 